\title{
INITIAL AND IN-SERVICE TRAINING FOR SECONDARY SCHOOL TEACHERS TO IMPLEMENT PROJECT-BASED LEARNING (PBL)
}

\author{
Ana María Ortiz-Colón ${ }^{1}$, Rafael Castellano-Almagro², Javier Rodríguez-Moreno', \\ \& Miriam Agreda Montoro ${ }^{1}$ \\ ${ }^{I}$ Department of Pedagogy, University of Jaén (Spain) \\ ${ }^{2}$ Department of Psyhcopedagogy, College Saint Mary of the Chapel (Spain)
}

\begin{abstract}
The continuous evolution of technology, the gradual abandonment of the industrial society and the increasingly standardised inclusion of emerging methodologies in the teaching and learning processes have a significant impact on the quality and way of life of the people involved in them, making it necessary to integrate them in detail into the education system itself through initial and ongoing teacher training.

This paper reflects on the initial university training that new Secondary Education teachers receive on new methodologies, specifically Project Based Learning (PBL), as well as the ongoing training that current teachers at this educational stage receive for their integration and incorporation as valid methodological systems for their daily classroom practice.

Thus, through an in-depth review of the scientific literature on the subject and our experience as active teachers in the "Master's Degree in Teaching Secondary Education, Baccalaureate, Vocational Training and Language Teaching" at the University of Jaen (Spain), we have addressed these issues, determining that the quality of the pedagogical training of new teachers does not correspond to the reality that they will later face in the classroom, In addition, the in-service training that in-service Secondary teachers receive depends on the intrinsic motivations of the teachers or the manifest resources and legal requirements at the time and not so much on the real needs that the students in the context may require.
\end{abstract}

Keywords: Formation, teachers, secondary education, PBL.

\section{Introduction}

The integration in the educational environment of technological resources that reinforce previously planned activities, the new socialising functions required of teachers, the inclusion of key competences and their evaluative environment, active methodologies that precede the teacher's teaching, collaborative or cooperative methodologies that abandon the individualistic idea of the student body in favour of a collective united in the common good, the new role of the teacher as a guide and not as a model pattern of the teaching-learning process and the loss of the reference value that the school, in general, and the teacher, in particular, represents for society, have generated the conception of strategies that facilitate the adaptation of the teaching work and its training to the challenges that the 21 st century society poses to the academic system (Hernández et al. , 2018; Marcelo and Vaillant, 2017; Monge and Gómez, 2018; Serrano and Pontes, 2017), proposing alternatives such as school-family collaboration (Egido and Bertran, 2017; Garreta, 2016; Parody et al., 2019), structural changes in the education system and in the role of the teacher (Calderón and Loja, 2018; European Commission, 2020; Pallarès et al., 2019; Singh, 2018) and, fundamentally, improvements in initial and in-service teacher training (Lombardi and Abrile, 2020; Santaolalla et al., 2020; Shawer, 2017).

For Senge (2017), teachers in the 21 st century have to teach what they do not know, so they must first unlearn and forget traditional pedagogical methods, innovate in new learning techniques and, therefore, train and relearn everything necessary for the new students in front of them.

On the other hand, some aspects of the quality of teaching have been directly related to teachers in terms of their training and qualifications, didactic programming, educational innovation and research, guidance and evaluation of the system itself (Tello and Aguaded, 2009), which is why there are already several authors who have conducted research on the involvement of teacher training and educational innovation from the teachers themselves (Iglesias et al, 2018; Kovacs, 2017; Monge and Gómez, 2018) since, as stated by De Vicente (2007), if we want to reform the education system, we must address the beliefs and initial training of teachers, generating quality training that is adapted to the current educational 
reality and needs, encouraging its protagonists and motivating them towards continuous development, since simply regulating different ways of teaching or changing curricula will not generate change if teachers do not meet the goals or adapt to the strategies of change through continuous training.

Thus, initial teacher training focused on new methodologies is a key part of change, but defining quality training is not always an easy process or always achieves the expected result.

\section{Initial university training that new secondary education teachers}

Secondary Education is a complex educational stage, in its articulation and development, which involves great efforts at all levels, and requires special attention in which teacher training occupies a prominent place (Esteve, 2006; Moreno, 2015). While Secondary Education was being democratised, reorganised, generating a new curriculum and adapting to the new times, the pedagogical and professional culture in line with it did not follow (Escudero, 2009).

Traditionally, the training of Secondary Education teachers has generated controversy and debate as it requires, to the same extent, academic knowledge or knowledge of a speciality and pedagogical and psychological content (León et al., 2011). Currently, in Spain, if we look at the courses and studies that enable pedagogical and didactic qualification with respect to the basic or initial training required to become a Secondary Education teacher, from the academic year 2009-2010, it will be defined by the Master's Degree in Teaching Secondary Education, Baccalaureate, Vocational Training and Language Teaching (Máster de Profesorado de Educación Secundaria, Bachillerato, Formación Profesional y Enseñanzas Idiomas, MFPES) implemented and regulated by Order ECI/3858/2007, following a complex web of laws, provisions and legal articulation that spans the last 35 years and in which not all teacher training is understood in the same way in all areas, by all agents involved, from all sectors and, broadly speaking, by all educational systems.

The contents with which future teachers are prepared, the professional competences they are expected to generate, the learning they manage to acquire and the opportunities and conditioning factors available to them to be able to develop them provide an essential basis within teacher training (Esteve, 2006) which, together with the involvement of the generic training section with specialisation in a subject and the professional section, which refers to specific training aimed at acquiring the basic requirements for the performance of the teaching profession, both theoretical and practical EURYDICE (2013) determine a wide variety of curricula. In our country, a consecutive model is determined, in which professional training is developed after having received the generic one, manifesting endemic basic problems since future teachers have first been trained as scientists and have generated a scientific professional identity and not that of teacher, the latter emerging as added and subordinated to the former, so it seems logical to think, following Lorenzo, et al, (2015), that the simultaneous model, which incorporates the three dimensions of initial training (general, theoretical professional and practical) in a single organisational structure, is more appropriate for obtaining the necessary requirements to produce good professionals because "teachers must be trained from both science and pedagogy and practice, which leads us to think that it would be more convenient to establish a professional degree" (p.753 ), although this is currently not satisfactorily achieved given the accumulation of problems involved in the design and development of teacher training in our country (Muñoz et al., 2019).

Although motivation for the person who wants to become a teacher must be an indispensable and necessary condition for the successful completion of initial teacher training and is linked to the age at which specific teacher training is accessed and the previous academic training from which it is accessed (Muñoz et al., 2019), working on the basis of the motivations, attitudes and expectations of future teachers, including an increase in practical training periods and the updating of this to active and more appropriate methodologies for 21 st century students, should be the basis on which this training is anchored, so that in this way, they acquire in the best possible way the competences they will require for the development of their professional role adapted to the needs of today's classrooms (Castellano-Almagro, 2020).

On the other hand, in today's 21 st century society, individualised, globalised and multicultural, the values and beliefs that are transmitted to future education professionals are a key element that can help to achieve or hinder the integration into this society of personal development, autonomy, community solidarity, peaceful coexistence and social collaboration, freedom, equity, commitment and respect for diversity (Díez-Gutiérrez, 2020), which is why in initial teacher training, a large part of the future and design of society as a whole is at stake, Although teachers are no longer considered a reference in values or a social or ethical model in today's society, their influence is undeniable in the transmission of some or other values that support or question the established sociological model, these values must be incorporated and made explicit in this initial training (Díez Gutiérrez, 2020). Despite all this, the fulfilment of these needs is currently far from reality. 


\section{MFPES and lifelong learning: active methodologies and ABP}

Although the legislative bases regulating initial teacher training in Secondary Education cover most of the points discussed above, different reasons or motivations have created a gap between the legislated intention and reality, with the new MFPES suffering from almost the same shortcomings as its predecessors: overcrowding, low quality, source of income for the university institution, little participation of secondary school teachers, time limitation of the training period to one academic year and the internship period to a single month, parallel realities and timetables that are difficult to reconcile in a real way and with student involvement, easy exit for frustrated professionals in their own professions for which they were trained, little methodological and didactic updating, etc. which has consolidated an incomplete and limited reform of the same (Gil et al., 2018; Muñoz et al., 2019; Tiana, 2013). Despite the above, the graduates and active noble teachers surveyed on their degree of satisfaction with their professional career and degree of training is good, although they recognise that they do not have sufficient competences when they first arrive in the classroom (Sonlleva, et al., 2019; Zurita et al., 2017), which means that teachers' perception of their own preparation to exercise the profession and be able to develop a fundamental role in the education system does not correspond with the initial training they receive or with the existing reality (Lorenzo et al., 2015). Despite this, other studies do point out the defects and weaknesses of this initial training, especially in the methodological aspect (Castellano-Almagro, 2020).

On the other hand, although the training of Secondary Education teachers has been adapted to the European Higher Education Area (EHEA) by requiring a Master's degree, with a minimum duration of 60 credits, this has not been the case in other aspects such as methodology, as the application of active methodologies focused on the student and aimed at the development of key competences and the basis for a society in continuous change, globalised and technified, has not yet been contemplated in its entirety. Although it is necessary to be trained in methodology and to experiment with it in order to be able to subsequently apply it (Pegalajar, 2015), there have been numerous experiences in the application of active methodology in the MFPES (Caldeiro et al., 2018; López, 2015) and others specifically in PBL (Imaz, 2015; Molina, 2019; Navarro et al, 2015; Salido, 2020), all of them positive and with encouraging results, but they are only specific aspects of a globality that shows how far there is still to go and the need for "PBL in initial teacher training to become a long-term experience and to be characterised by the breadth of knowledge, as this is the orientation that this model should acquire in non-university education classrooms" (Salido, 2020).

With regard to lifelong learning, and based on the methodological change implied by the national education law, LOMCE (2013), the Education Administration took a leading role in it, making possible a range of teaching resources of methodological quality available in digital media, promoting the use of ICT, virtual learning environments, etc., all supported by heavy investments that will lead to different results. However, there is still a need for better and more ongoing training from and for teachers that makes it possible to share successful methodological experiences (Castellano-Almagro, 2020), with greater temporality for practice and avoiding the development through a set of fixed and consolidated modalities that have been so poorly valued by the teachers involved (Bazán et al., 2010; Escudero, 2017).

At present, we can find many lifelong learning plans, but there is little innovation, resorting to training systems whose content, learning and practices are rarely implemented in the classroom (Imbernon, 2016). The remedy is to improve the design of the content of this training, seeking to incorporate the demands of daily teaching practice so that it is possible to improve and solve priority professional problems in differentiated contexts (Bazán et al., 2010) by combining training and practice.

\section{Conclusion}

Bearing in mind all of the above, it is essential when facing, debating or designing initial and in-service teacher training to consider and have clear answers to key questions such as: What is the profile of the teacher we are trying to obtain or the challenges they are going to face? What are the social, economic, academic, cultural, etc. objectives they must achieve in the development of their profession? What are the essential values that we must transmit to our teachers so that they can also be educators? What is the hidden curriculum that prevails among students and what impact does it have on them? What are the professional competences that they are expected to develop, strengthen and put into practice? What are the parameters, therefore, that define a teacher as a competent professional? Is the teacher born or made? Being aware of the need for a fluid and extensive dialogue between all the parties involved in the preparation of this training, analysing in a real and reliable way the needs of future teachers in order to give the best professional response to their future students and to society. 
Generating a simultaneous system, differentiated by stages and with a practical load in accordance with and appropriate to the initial training itself, with a real basis based on active methodologies, is essential for the success of initial teacher training in Secondary Education which, together with the intrinsic motivation of teachers, allows the profession to adapt to the needs of today's students, as we need our education systems to have the capacity to attract and captivate the best candidates to become teachers, through the means available or those available at the time (Marcelo, 2009).

We believe that the creation of lifelong learning groups in action research networks would solve part of the training needs of teachers, being the best context for the inclusion of new methodologies or educational innovation, coinciding with the study by Barba et al. (2018) and for PBL, as shown by Botella and Ramos (2019) in their research.

\section{References}

Barba, R., Sonlleva, M. y García, N. (2018). Presencia, participación y progreso: el aprendizaje basado en proyectos en la trayectoria de una maestra en formación. Revista Electrónica Interuniversitaria de Formación del Profesorado, 21(2), 13-25.

Bazán, A., Castellanos, D., Galván, G. y Cruz, L. (2010). Valoración de profesores de Educación Básica de Cursos de Formación Continua. REICE Revista Iberoamericana sobre Calidad, Eficacia y Cambio en Educación, 4 (8).

Botella, A. y Ramos, P. (2019). Investigación-acción y aprendizaje basado en proyectos. Una revisión bibliográfica. Perfiles educativos, 41(163), 127-141.

Caldeiro, M., Sarceda, C. y García, R. (2018). Innovación e investigación en educación superior: desarrollo de competencias digitales y aplicación de metodologías activas en futuros docentes de FP. En R. Roig-Vila (Ed.), El compromiso académico y social a través de la investigación e innovación educativas en la Enseñanza Superior (pp. 1212-1221). Barcelona: Octaedro

Calderón, P. y Loja, H. (2018). Un cambio imprescindible: el rol del docente en el siglo XXI. ILLARI, (6), 35-40.

Castellano-Almagro, R. (2020). Aprendizaje basado en proyectos (ABP). Análisis de las necesidades formativas del profesorado de educación secundaria (Tesis Doctoral). Jaén: Universidad de Jaén.

De Vicente, P. (2007). Variaciones sobre un vínculo inquebrantable: el papel de las nuevas tecnologías en el desarrollo profesional docente. En J. Cabero (Ed.) Nuevas tecnologías en la formación flexible y a distancia (pp. 127-158). Sevilla: Kronos.

Díez-Gutiérrez, J. (2020). Valores transmitidos en la formación inicial del profesorado. Educar, 56(1), 129-144. https://doi.org/10.5565/rev/educar.1079

Egido, I. y Bertran, M. (2017). Prácticas de colaboración familia-escuela en centros de éxito de entornos desfavorecidos. Pedagogía Social. Revista Interuniversitaria, 29, 97-110.

Escudero, J.M. (2009). La formación del profesorado de Educación Secundaria: Contenidos y aprendizajes docentes. Revista de Educación, 350, 79-103.

Esteve, J. (2006). La profesión docente en Europa: perfil, tendencia y problemáticas. La formación inicial. Revista de Educación, 340, 19-40.

European Commission/EACEA/Eurydice, (2020). Equity in school education in Europe: Structures, policies and student performance. Eurydice report. Luxembourg: Publications Office of the E.U.

EURYDICE (2013). Key Data on Teachersad School Leaders in European. Brussel: Publications EU.

Garreta, J. (2016). Fortalezas y debilidades de la participación de las familias en la escuela. Perspectiva Educacional, 55(2), 141-157.

Gil, R., León, A., Calderón, D. e Íñigo, V. (2018). Evaluación de competencias en el Máster en Formación de Profesorado: un estudio exploratorio en una actividad de foro. Revista Educación y Tecnología, 12, 1-16.

Hernández, R., Orrego, R., y Quiñones, S. (2018). Nuevas formas de aprender: La formación docente frente al uso de las TIC. Propósitos y Representaciones, 6 (2), 671-685.

Iglesias, M., Lozano, I. y Roldán, I. (2018). La calidad e innovación educativa en la formación continua docente: un estudio cualitativo en dos centros educativos. Revista Iberoamericana de Educación, 77(1), 13-34. https://doi.org/10.35362/rie7713090

Imaz, J. (2015). Aprendizaje Basado en Proyectos en los grados de Pedagogía y Educación Social: “Cómo ha cambiado tu ciudad?” Revista Complutense de Educación, 26(3), 679-696.

Imbernón, F. (2016). Los retos educativos del presente y del futuro. La sociedad cambia, ¿y el profesorado? Revista Internacional de Formação de profesores, 1, 121-129. 
Kovacs, H. (2017). Learning and Teaching in Innovation: why it is important for education in $21 \mathrm{st}$ century. Neveléstudomány, 5, 45-60. Doi:10.21549/NTNY.18.2017.2.4.

Lombardi, G. y Abrile, M. (2020). La formación docente como sistema: de la formación inicial al desarrollo profesional, en C. Velaz y D. Vaillant (Eds.), Aprendizaje y desarrollo profesional docente (pp. 59-66). Madrid: Santillana y EOI.

López, F. (2016). Metodología participativa en la enseñanza universitaria. Madrid: Narcea

Lorenzo, J., Muñoz, I. y Beas, M. (2015). Modelos de formación inicial del profesorado de Educación Secundaria en España desde una perspectiva europea. Revista Complutense de Educación, 26(3), 741-757.

Marcelo, C. (2009). Los comienzos en la docencia: un profesorado con buenos principios. Profesorado. Revista de currículum y formación de profesorado, 13 (1), 1-25.

Marcelo, C. y Vaillant, (2017). Desarrollo profesional docente ¿Cómo se aprende a enseñar? Narcea.

Molina, M. (2019). El Aprendizaje Basado en Proyectos (ABP) en la formación metodológica del profesorado del Grado de Educación Primaria. Enseñanza \& Teaching, 37(1), 123-137.

Monge, C. y Gómez, P. (2018). Implicaciones de la formación e innovación en la mejora de la calidad educativa. En C. Monge López y P. Gómez Hernández (Coords.), Innovando la docencia desde la formación del profesorado (pp. 23-46). Madrid: Síntesis.

Moreno, A. (2015). Enfoques en la formación docente. Ra Ximhai, 11 (4), 511-518.

Muñoz, G., Rodríguez, P. y Luque, M. (2019). La formación inicial del profesorado de educación secundaria en España: perfil y motivaciones del futuro docente. Educación XXI, 22(1), 71-92.

Navarro, I., González, C. y Botella, P. (2015). Aprendizaje Basado en Proyectos: diferencias percibidas en la adquisición de competencias por el alumnado universitario. Revista de Psicología y Educación, 10 (1), 55-76.

Pallarès, M., Chiva, O., Planella, J. y López, R. (2019). Repensando la educación. Perfiles Educativos, 41(163), 123-137.

Parody, L., Santos, M., Alcalá, M. y Isequilla, E. (2019). El desafío educativo del siglo XXI: relevancia de la cooperación entre familia y escuela. Espiral. Cuadernos del Profesorado, 12(24), 19-29.

Pegalajar, M. (2015). Metodología docente en el máster de formación de profesorado de educación secundaria: valoración del alumnado. RUSC. Universities and Knowledge Society Journal, 12(3). págs. 61-71. doi http://dx.doi.org/10.7238/rusc.v12i3.2246

Salido, P. (2020). Metodologías activas en la formación inicial de docentes: Aprendizaje Basado en Proyectos (ABP) y educación artística. Revista de Currículum y Formación de Profesorado, 24(2), 120-143. DOI: 10.30827/profesorado.v24i2.13565

Santaolalla, E., Urosa, B., Martín, O., Verde, A. and Díaz, T. (2020). Interdisciplinarity in Teacher Education: Evaluation of the Effectiveness of an Educational Innovation Project. Sustainability, 12, 6748, 1-23. doi:10.3390/su12176748

Senge, P. (2017). El profesor del siglo XXI tiene que enseñar lo que no sabe. El País. Retrieved, March 2, 2021 from: https:/elpais.com/economia/2017/01/15/actualidad/1484514194 176496.html

Serrano, R. y Pontes, A. (2017). Diferencias entre expectativas y logros en las competencias del Prácticum del Máster de Formación del Profesorado de Enseñanza Secundaria. Revista Electrónica Interuniversitaria de Formación del Profesorado, 20(1), 1-18.

Shawer, S. (2017). Teacher-driven curriculum development at the classroom level: Implications for curriculum, pedagogy and teacher training. Teaching and Teacher Education, 63, 296-313.

Singh, O. (2018). Role of Teachers in 21th Century: Opportunities and Challenges. International Journal of Scientific Research and Review, 7 (5), 1-7. https://www.researchgate.net/publication/342233089

Tello, J. y Aguaded, J. (2009). Desarrollo profesional docente ante los nuevos retos de las tecnologías de la información y la comunicación en los centros educativos. Pixel-Bit. Revista de Medios y Educación, 34, 31-47. http://www.redalyc.org/articulo.oa?id=36812036003

Tiana, A. (2013). Los cambios recientes en la formación inicial del profesorado en España: una reforma incompleta. Revista Española de Educación Comparada, 22, 39-58

Zurita, F., Viciana, V., Padial, R. y Cepero, M. (2017). Niveles de satisfacción hacia el grado de maestro en alumnos de último curso. Revista de Currículum y Formación del Profesorado, 21 (1), 349-367. 